\title{
THE USE OF THE PAST TENSES IN EUROPEAN PORTUGUESE BY SLOVENE STUDENTS: THE CAUSES OF POSSIBLE DEVIATIONS
}

\section{MOJCA MEDVEDŠEK
BLAZKA MULLER \\ mojca.medvedsek@ff.uni-lj.si \\ blazka.muller@ff.uni-li.si}

\section{University of Ljubljana, Slovenia}

in collaboration with Beatriz Moreira de Oliveira

\section{University of Porto}

\begin{abstract}
The analysis presented in this article aims to ascertain what conditions of use imply deviations in the use of the Past tenses in European Portuguese (PPS, PPC, PI, PMQC) by Slovene learners of Portuguese, A2-B1 level (QECRL), trying to find explanations for its occurrence. The analysis shows the contrast between European Portuguese and Slovenian language in the domain of the Past tenses in terms of tense and aspect, describes the most frequent and evident deviations in a corpus, consisting of the various genres of texts, worksheets, completed by the students. Several presumptions were verified in the qualitative analysis. Among them, the deviations are in most cases due to the fact that in the sphere of the past, the Slovene language is operating with only one paradigm of the past sphere, the preteklik (Past tense), which is supposed to mark all the temporal and aspectual nuances of four Portuguese past tenses of the Indicative. The article tries to underline the different way of marking time and aspect in the respective languages and therefore the students' difficulties in the perception of temporal and aspectual perfect / imperfect conceptualization.
\end{abstract}

Keywords: Past tenses, European Portuguese, Slovenian, deviations, temporal and aspectual values, analysis 


\section{Introduction}

The distinction between Pretérito Perfeito Simples (PPS), Pretérito Imperfeito (PI), Pretérito Perfeito Composto (PPC) and Pretérito MaisQue-Perfeito Composto (PMQPC) of Indicative in European Portuguese (PE) is a typical source of difficulties for PE students, especially for those whose mother tongues do not have the same verbal distinction in terms of temporal and aspectual values. One of these cases can be exemplified by Portuguese students whose L1 is Slovenian (ESL).

In general, we can say that both PE and ESL have temporal verbal inflection, however, the number of verbal tenses in ESL is scarcer than in PE. Furthermore, in the past sphere, the Slovenian language only has one Past tense which is preteklik (Pretérito) in comparison with the Portuguese tenses, Pretérito Perfeito Simples (PPS), Pretérito Imperfeito (PI), Pretérito Perfeito Composto (PPC) and Pretérito Mais-Que-Perfeito Composto (PMQPC) of Indicative that in PE are the 'grammatical tenses' that we associate with the events carried out in a 'past' 1 .

As already pointed out, the Slovene language is operating with only one paradigm of the past sphere the preteklik that is supposed to mark all the temporal and aspectual nuances contained in the forms of the four Portuguese past tenses of the Indicative. On the other hand, the EP does not formally mark the aspect, while the Slovenian verbal system is characterized by the category of the verbal aspect as a morphological category. Slovenian verbs, in principle, are either imperfective or perfective, and, therefore, uniaspectual ${ }^{2}$. Furthermore, it is supposed that the difficulties in choosing the adequate past tense form for the Slovenian learners also appear due to the problem of the perception of temporal and aspectual nuances that each of the Portuguese past paradigm in particular contains.

The key aim of this study is to answer the questions that arise from the exposed facts and presumptions or other factors. In line with this view, this article deals with a specific situation of Slovene students of PE as a foreign language (L2).

The quantitative and qualitative analysis is based on the contrast between PE and ESL in terms of tense and aspect and describes the most frequent deviations in a corpus of students' written productions. The

1. cf. Nunes Correia, C. In: Markič et alt.: Ljubljana, ZIFF, 2013: p. 78.

2. cf. Markič, J. In: Markič et alt.: Ljubljana, ZIFF, 2013: p. 65. 
objective is to verify what conditions of use imply more deviations from the use of the past tenses of PE by 12 Slovene learners of Portuguese, B1 level (QECRL), with Slovene L1, and tries to find some explanations for their occurrence.

The first part of the given article describes from a contrastive point of view the main and basic features of the past sphere of the verbal system of both languages, EP (L2) and ESL (L1).

In the second part, the article presents the pilot study that focuses on the use of past tenses in PE. In discussion, some common errors of Slovene students resulting from the pilot study between PE and ESL are explained.

\section{Past tenses: PE in contrast with ESL}

Bearing in mind the observations made above on the functioning of the two languages in relation to mark the tense and aspect, we present below, in a succinct way, some characteristics of these languages on this issue.

In general, time is associated with the localization of the situation, both in relation to the enunciation time and to another time marked linguistically. The aspect, in turn, concerns the internal temporal structure of the situation. In languages like PE, some verbal tenses can convey both temporal and aspect information.

The PPS fundamentally gives the past temporal information, without operating any aspectual changes. On the contrary, the PI can provide temporal information, but it can also function as an aspect operator. The PPS conveys the temporal information in relation to the enunciation time or in relation to another time expressed linguistically. As for the aspect, the PPS systematically gives the information that the situation is concluded, without changing the respective aspectual class ${ }^{3}$.

With regard to the PI, although it can locate situations in the past, it rarely does so in relation to the enunciation time. It is typically an anaphoric time, that is, dependent on another time expressed linguistically. Because it is also an extended time, it gives the duration of the situations that marks and, therefore, it can eventually transform events into states in terms of aspect.

The PPC is close to some compound tenses in the verbal characterization of the Romance languages (passé composé (French),

3. Cf. Oliveira, Krakow, 2019: p. 449. 
have the meaning either perfective or imperfective ${ }^{6}$. To resume, in contrast to PE, the Slovenian preteklik, concerning the internal temporal structure of the situation, with relevant distinctions between the presence or absence of dynamism, telicity or duration, among others, marks the aspectual values, using the perfective or imperfective form of the uniaspectual verb and adverbial markers, both aspectual and temporal.

\section{Empirical study}

After a brief description of the functioning of the two languages in relation to mark the tense and aspect in the past tenses, we present below the pilot study that was carried out in May 2019. First, we will describe the choice of the texts used for this research, secondly, we will make a quantitative analysis of the data and discuss the obtained results.

\subsection{Pilot study}

It is important to note that at the Faculty of Arts of the University of Ljubljana, Portuguese language and culture are taught as elective subjects Portuguese 1, Portuguese 2, Portuguese 3 within the study of Romance languages. The didactic textbooks used in the first two levels is Português XXI $(1,2)$ of the Portuguese publishing house Lidel - Ediçōes Técnicas. The students who attended the elective subject Portuguese 2 and participated in the research, supposedly reached the level A2-B1 after attending elective subject Portuguese 1 (60 hours) and after almost finishing the next level that would give them the proficiency B2 (additional 50 hours in the summer semester of 2019, Portuguese 2) - thus the participants in the study already obtained some basic knowledge about the use and the forms of all four past tenses in question.

The pilot study was performed with twelve students aged between 20 to 25 years, who study one of the other Romance languages, i.e. Spanish, Italian or French in their basic academic program.

The students had some practice with similar text material and exercises from the grammar books such as Gramática Ativa 1, 2011.

\subsection{Presentation of the selected texts}

The present section of this article is focused on the review and analysis of the selected texts according to their textual genre, as well as the typology of the exercises undertaken in this investigation. Our aim was to select current texts that reflect the linguistic and communicative realities of the target language. We believe that the assessment of the

6. Cf. Merše, Ljubljana, ZRC,1995: p.28. 
students' grammatical knowledge must be conducted throughout authentic speeches (in both oral and written form) instead of isolated and decontextualized sentences. Moreover, we have considered the adequacy of the texts to the focus of our research and the target public and took into account the proficiency level of the students (B1).

To carry out our investigation, three authentic texts were carefully chosen. These texts were not produced or published for didactic purposes and are written in PE (the variant that is being studied by the target public). The elected texts belong to distinct textual genres, such as: a chronicle from the Portuguese magazine "Visão" from the year of 2019 and that is part of a column named Nós Lá Fora in which Portuguese citizens share experiences about their lives across the world; a narrative from the year of 2019 extracted from the segment Viajantes of a monthly Portuguese online magazine Volta ao Mundo dedicated to the stories and testimonies of Portuguese travellers; and lastly, a dialogue transcribed from an interview of the television programme Só Visto! from the Portuguese national channel RTP1 (Rádio e Televisáo Portuguesa) from the year of 2014.

The selected text (A) integrated in the first worksheet given to the students is a chronical entitled Isto aqui é um pouquinho de Brasil, desse Brasil que canta e é feliz... Besides its literary nature, this textual genre also comprises the author's opinion, who describes a determinate social and cultural reality. In the text A, the author narrates and describes in the firstperson singular a set of real past experiences, as if she is dialoguing with the reader. As a result of a narrative in the past, the verbs appear conjugated in the tenses PPS and PI of the Indicative. Therefore, the first worksheet's purpose is to analyse the learners' correct distinction and use of these two verbal tenses. Apart from that, we privileged the inclusion of this textual genre not only for its brevity, but also for its simple, spontaneous and hybrid language - considering that it balances between the oral language and the literary discourse.

The second text (B) is text from the press media named "Largaram tudo e partiram de bicicleta para uma viagem de dois anos". This article portrays several travels, adventures and emotional journeys engaged by two travellers. Our aim is to analyse the students' knowledge concerning the use of the verbal tenses PPS and PI of the Indicative, in contrast with PPC of the same mood, i.e., if they are capable of distinguishing a completed or punctual action in the past (PPS) from a continuous or ongoing action also in the past (PI) as well as from an action started in 
the past but not concluded and prolonged until the present time (PPC). The relevance of this text is also due to the narration of long-ago moments experienced by the author and the travellers combined with descriptions of actions, feelings and emotions that have remained until the present day. Just as the previous text, this short narration is written in a language, which exemplifies the real and everyday usage of communication in the target language.

The last selected text (C) for our study is a dialogue extracted from a television interview called Henrique Sá Pessoa em entrevista com Silvia Alberto in which the main characteristic is the direct speech. It can be described as an informal conversation between the interviewer and her invited guest that presents signs of oral speech. The employed form of address is informal, in the second-person singular - tu (you). Despite de informal language, the speech is organized in a coherent way since it is an interview. The interviewed uses of the verb tenses PPS and PI in addition to PPC and PMQPC of the Indicative. Through this text we intend to contrast the usage of the four verb tenses: PPS in contrast with PI of the Indicative and PPC in contrast with PMQPC of the Indicative.

The adopted typology of the created exercises consists of the selection of the most appropriate verb tense in a certain sentence and context. Two answer options are offered to the students according to the focus of the analysis. Thus, it is possible to evaluate the way in which the learners of Portuguese foreign language whose first language belongs to the Slavic language group (in the present case, Slovenian) are capable of using and distinguish the verb tenses in the past. Besides that, it is possible to analyse the grammatical contexts in which mistakes might occur and the students' main grammatical fragilities. We have presumed that our target public possess the structural knowledge concerning the conjugation of the verbs in the adequate person and number, and for this reason, the students can find the verbs already inflected in the correct form.

Lastly, it is important to mention that none of the texts was modified for the purpose of this study. We reduced their lengths so that the exercises could be solved during the time confined to one lesson $(60 \mathrm{~min})$.

\subsection{The results of the analysis}

The results of the analysis of are the following:

a) In the text $A$, where the purpose is to analyse the learners' correct distinction and use of PPS and PI, the percentage of the deviations related to the wrong selection of the verbal tense is 
$26 \%$, presumably due to the general problem of the perception of Slovenian learners concerning the temporal and aspectual content of the verbal forms of PE. In line with this view, the factor contributing to this result could be also vague or minimal occurrence of temporal or aspectual markers in the respective text. Moreover, in the text $\mathrm{A}$, the unexpected result is a high number of occurrences of the deviation (45\%) in the case of the verb ser (to be).

b) In the text $\mathrm{B}$, where the selection was to be made among the three past tenses of the PE, the number of deviations was much higher (32\%) than in the text $\mathrm{A}$. The most frequent deviation was a selection of PI instead of PPC or vice versa in the sequences that had no explicit temporal or aspectual markers.

c) In the text $\mathrm{C}$, where the selection was to be made among the four past tenses of the PE, the number of deviations was as almost as high as in text $\mathrm{B}(31 \%)$. The most frequent deviation was a wrong selection of PI instead of PPC in the sequences that had no explicit temporal or aspectual markers. The highest number of deviations was related to the use of PI instead of PPS in the sequences containing the adverb always - sempre.

\subsection{Discussion}

The analysis of the pilot study offers some general observations.

First, on the basis of the results that derive from all tree texts of the pilot study as described above, it seems that the majority of the deviations from the use of the past tenses of PE by Slovene learners (L1) of Portuguese arise from the different way of marking the temporal and the aspectual values in PE and ESL. The students, as the results show, are confronted to the problem of perceiving the aspectual domain that in PT occur through the verbal tenses and in ESL through the lexical contents of the verbs, namely in terms of aspect.

Furthermore, we presume that the reason of the detected difficulties origins in the fact that the Slovene language is operating with only one paradigm of the past sphere, which is the preteklik (Pretérito) that is supposed to mark all the temporal and aspectual nuances contained in the forms of the four Portuguese past tenses.

On the basis of this analysis, it could be claimed - as probably main general observation -that the difficulties for the Slovenian learners appear due to the problem of perception of temporal and aspectual nuances that 
each of the Portuguese past paradigm in particular contains.

Despite the fact that the aspectual difference between perfective and imperfective values of the grammatical category aspect is clear to the Slovenian students, in the text A the deviations often occur in the choice of PPS and PI. The authors of this study believe that when reflecting about these aspectual concepts in Portuguese, the time component of both tenses may be sufficiently emphasized, but certainly too little attention is paid to the aspectual values of these paradigms. As the solved examples show, it is otherwise clear to the Slovenian students that PPS, in general, denotes the perfective (concluded) aspectual value and its contrast with PI. It is obvious that this tense in the interpretations of language is presented in a sufficiently clear way as a paradigm that characterizes the description, background, habits, etc. and is, in the texts A, B and C, appropriately selected. Nevertheless, deviations appear in almost $26 \%$ of the cases. The authors of this study attribute these to the general observations, as putted above, and to the fact that in the case of the sentences with no temporal and aspectual markers, the choice for the appropriate temporal form in terms of verbal tense is more difficult.

Still within the domain of adverbial markers, the research revealed that when a sequence has a clear adverbial marker (e.g. in the text C, aos 15 anos, em 2013, etc.) the choice of tense doesn't represent major problems. Nevertheless, the research revealed a major problem with a Portuguese adverb sempre, always, (84\% of deviations) that Slovenian students, participating in the study, in the majority of cases combined with PI. The reason could be in the fact that this adverb in ESL (vedno) implies a durative and non-perfective aspect and is generally used with the imperfective form of the verb and, if it is a past sphere in question, this form is used in preteklik. In PT, the temporal adverbs are not always exclusively used either with PPS or with PI. According to the result, this perception is not completely present to the students. It appears that the learners operate the direct transfer of the aspectual content of the adverb, in the case of Slovenian vedno, combining the equivalent sempre in PT with $\mathrm{PI}^{7}$.

Considering the unexpected result in a text A (a high number of

7. For the further discussion cf. Cunha \& Cintra (2017) that suggest the example of a sentence in Pertérito Perfeito Simples which also employs the adverb sempre: "Os homens do mar tiveram sempre uma grande ternura pelas aves" (R. Brandão, p. 164, apud Cunha \& Cintra, 2017, p. 469). 
occurrences of the deviation in the case of the verb ser (to be)), the authors of the study suppose that these results cannot be attributed to the fact that ESL operates with only one verb (biti) that embraces the values of both Portuguese verbs ser and estar ${ }^{8}$. The authors of the study believe that the reason for these deviations resides in the same problem as suggested in the case of the other PT verbs: in the perception of the perfect or imperfect aspect of an individual linguistic situation, that is, in the perception of temporal and aspectual nuances that each of the Portuguese past paradigm in particular contains.

In the text $\mathrm{B}$, where the selection was to be made among the three past tenses of the PE, the number of deviations was much higher (32\%) than in the text $\mathrm{A}$. The most frequent deviation was a selection of PI instead of PPC or vice versa in the sequences that had no explicit temporal or aspectual markers. The authors of the research could attribute these results to the fact that both verbal tenses generally have an imperfective aspectual value. It seems that due to this fact the students obviously did not perceive a clear distinction between the two tenses, not having clearly present that the PPC, generally in the contrary with PI, includes in its definition the moment of the enunciation?

Based on the results of the text $\mathrm{C}$, we could claim that that most students in cases where the adequate solution was PMQPC, used this form correctly. The perception of temporal situation of the precedence of a past act to another past act and the parallelism with the verbal situation in ESL (even if this verbal tense is inactive in oral language) seem satisfactory.

As for the use of texts in the research, the authors, as explained above, privileged the inclusion of short textual genres not only for its brevity, but also for its simple, spontaneous language (dialogue), which exemplifies

8. Cf. Müller, B. In: Markič et alt., Ljubljana, ZIFF, 86: "Ser (marca características que fazem parte da natureza permanente de pessoas e coisas, propriedades permanentes que definem um ser ou um objeto, localizaçao de coisas, etc.) (...) estar (exprime estados físicos e psicológicos ocasionais, a localizaçao temporária de seres e objetos, o tempo atmosférico)."

9. Cf. Correia C. In: Markič et alt., Ljubljana, ZIFF, 2013, 103: "(...) de incluir na sua definição o momento da enunciação que permite considerar o pretérito perfeito composto um tempo gramatical com características próprias.Alguns linguistas defendem, por isso, que, em portugues, este tempo gramatical (cf. Campos 1984, por exemplo) nao é um tempo gramatical marcador de tempo passado (pretérito), mas um marcador aspetual, e, dentro desta categoria, como marcador aspetual de imperfetividade, isto é, de nao construçao de um estado resultante dos acontecimentos linguísticos em que ocorre." 
the real and everyday usage of communication in the target language. Even though the context of the texts were simple, the authors, contrary to their expectations, could observe that that factor did not help to the learners to perceive a distinction between temporal and aspectual nuances of the Portuguese past paradigm, especially in the sequences that didn't contain adverbial markers. 


\section{CONCLUSION}

The main purpose of this article was to shed a new light on a specific situation of Slovene students (L1) of Portuguese (L2) A2-B1 level (QECRL), analysing the students' knowledge concerning the use of the verbal tenses PPS, PMQPC, PI and PPC of the Indicative, i.e., if they are capable of distinguish a completed or punctual action in the past (PPS, PMQPC)) from a continuous or ongoing action also in the past (PI) as well as from an action started in the past but not concluded and prolonged until the present time (PPC). In order to achieve this goal, the authors of this article, initially, have described the main features of the past tenses of the verbal systems of PE and ESL, in particular from the points of view of temporal and aspectual values in both languages. Afterwards, a pilot study was carried out. The analysis of the pilot study presented in this article aims to ascertain what conditions of use imply deviations in the use of the Past tenses in PE (PPS, PPC, PI, PMQPC) by Slovene learners of PE, trying to find explanations for their occurrence.

The article tried to consider the decisive question whether the cause of the tense use problems that Slovene learners of PE have is merely the absence of the vaster number of past tenses of the Slovene verbal system or there are other factors, related to the perception of the temporal and aspectual contents of the past tenses.

A number of interesting observations arose during the procedures described in the article. On the basis of this analysis, it could be claimed that the cause of the tense use problems can undoubtedly be attributed to the absence of the vaster number of past tenses in ESL verbal system in comparison to $\mathrm{PE}$, nevertheless, the study revealed also that the cause of the deviations seem to be related to the presumed weak perception of temporal and aspectual nuances that each of the Portuguese past paradigm in particular contains. It is not to be neglected that the results revealed that in the case of the sentences with no temporal and aspectual markers, the choice for the appropriate temporal form in terms of verbal tense was more difficult.

By way of conclusion, there are certain issues we would like to consider.

The results reveal that the distinction between PE Past tenses is not stabilized at level B1, which is understandable, given that the contrast between these tenses is still to be improved at this level. Slovene students need a relatively large amount of training to master the use of the past tenses in PE, which number is significantly higher than in ESL. In order 
to that, they need much more practice to reach an acceptable level of knowledge. In trying to identify the problems related to the training of the selection of the correct form of past tense, the teacher must identify the temporal and aspectual interaction between the mother tongue and the foreign language in question. In this sense, contrastive analysis can have an important role in students' awareness of their tense selection errors and in improving their knowledge of the L2 verbal system.

It is more than obvious that the pilot study, carried out for the aim of this article, will serve as a basis for the preparation of didactic material for future Portuguese language students. In line with this view, the pilot study opens some potential avenues of future researches, which are, there is no doubt, needed. 


\section{Bibliography:}

Text A: http://visao.sapo.pt/nos-la-fora/2019-05-07-Isto-aqui-e-umpouquinho-de-Brasil-desse-Brasil-que-canta-e-e-feliz

Text B: https://www.voltaaomundo.pt/2019/10/16/largaram-tudo-e-

partiram-de-bicicleta-para-uma-viagem-de-dois-anos-a/viajantes/viajantesextraordinarios/16805/

Text C: https://www.youtube.com/watch?v=SQG06c5HGyw

Campos, M. Henriqueta Costa, Pretérito Perfeito Simples / Pretérito Perfeito Composto: uma oposiçâa aspectual e temporal, in Tempo, aspeto emodalidade. Estudos de linguistica Portuguesa, Porto, Porto Editora, 1997.

Cunha, Celso \& L. Lindley Cintra, Nova Gramática do Português Contemporâneo, Lisboa, Ediçóes João Sá da Costa, Lisboa, 1984.

Cunha, Celsa \& L. Lindley Cintra, Nova Gramática do Português Contemporâneo, Rio de Janeiro, Edição Lexicon, 2017.

Lečič, Rada, Slovenski glagol : oblikoslovni priročnik in slovar slovenskih glagolov (Slovene verb: a morphological manual and dictionary of Slovene verbs), Založba ZRC SAZU, Ljubljana, 2005

Markič, Jasmina / Correia, Clara Nunes et alt.: Descriçôes e Contrastes Tópicos de Gramática Portuguesa com Exemplos Contrastivos Eslovenos/Opisi in primerjave. Poglavja iz slovnice portugalskega jezika s kontrastivnimi ponazoritvami v slovenščini, Ljubljana, Znanstvena založba Filozofske fakultete Univerze v Ljubljana, ZIFF, 2013.

Medeiros, Vanise Gomes de, Os passados no ensino de português para estrangeiros, Porto, Soletras 1.2, 2001.

Merše, Majda, Vid in vrstnost glagola v slovenskem knjižnem jeziku 16. stoletja, Ljubljana, SAZU, 1995.

Miklič, Tjaša, Metafore o načinih gledanja na zunajjezikovna dejanja $v$ obravnavanju glagolskega vida, FF, 2007.

Oliveira, Fátima, Alguns Aspectos do Aspecto. In: Actas do VII Encontro da Associação Portuguesa de Linguistica, Lisboa, 1991.

Oliveira, Fátima, Algumas Peculiaridades do Aspecto em Português. In: Actas do Congresso Internacional Sobre o Português, Vol. II, Lisboa, 1994.

Oliveira, Fátima, Tempo verbal, in Gramática do português / org. Eduardo Paiva Raposo ...[et al] ; colab. Graça Vicente, Rita Veloso, Lisboa, Fundação Calouste Gulbenkian, 2013.

Oliveira, Fátima, $O$ uso do Pretérito Imperfeito e do Pretérito Perfeito do 
Indicativo em português europeu por estudantes com cantonês como L1, Krakow,Studia Iberystyczne n. 18, 2019

Toporišič, Jože, Slovenska slovnica. Maribor, Obzorja, 1984.

Žele, Andreja, Pomensko-skladenjske lastnosti slovenskega glagola, Založba, Ljubhljana, ZRC SAZU, 2012. 